\title{
High apostome ciliate endoparasite infection rates found in the Bering Sea euphausiid Thysanoessa inermis
}

\author{
Gerard M. Capriulo', Marco J. Pedone ${ }^{1}$, Eugene B. Small ${ }^{2}$ \\ ${ }^{1}$ Environmental Sciences Department, State University of New York at Purchase, New York 10577, USA \\ ${ }^{2}$ Department of Zoology, University of Maryland at College Park, Maryland 20742, USA
}

\begin{abstract}
Samples of the Bering Sea euphausiid Thysanoessa inermis (Kroyer), collected at 2 stations in the Bering Sea, and consisting primarily of first-year adult females and last-furcilia-stage sub-adults, were studied to determine the percentage infected by the apostome ciliate endoparasite Collinia beringensis (Capriulo \& Small). In both groups of krill, infection percentage was found to be extremely high, at 98 and $68 \%$ respectively. The higher rate of $98 \%$ was found in the sample composed of larger and older euphausiids. Such infestation rates suggest that these ciliates may be important modifiers of euphausid production.
\end{abstract}

Euphausiids (krill) represent a significant proportion of the biomass in the world's oceans and are an important food source for numerous species of whales, fish, seals and birds (Mauchline \& Fisher 1969, Mauchline 1980). Given their key ecological role, it is important to identify factors which would negatively impact euphausiid biomass and productivity.

Capriulo \& Small (1986) reported the discovery of a previously unknown species of apostome ciliate (Collinia beringensis) living endoparasitically in the haemocoel cavity of the Bering Sea euphausiid Thy- sanoessa inermis (Krøyer). Some of the krill contained extremely high numbers of these ciliates, packed so tightly that normal ciliate cell shapes were altered (Fig. 1). Such high densities of parasites in these planktonic crustaceans suggest the likelihood of physiological impairment to the infected host, perhaps leading to reduced growth, egg production and even death.

To begin to assess the impact ot these parasites on krill populations we examined the percentage infection within 2 separate samples of Thysanoessa inermis collected from the Bering Sea on 2 May (Stn 2012) and 8 May (Stn 2033) 1981, by Dr Sharon Smith and D. Ninivaggi, as part of Brookhaven National Laboratories' involvement in the National Science Foundation funded PROBES project. Samples were taken at night via horizontal tow with a $1 \mathrm{~mm}$ mesh plankton net, from surface water (Stn 2012) and $15 \mathrm{~m}$ depth (Stn 2033), and fixed in $10 \%$ buffered formalin. The 2 euphausiid samples were characterized with respect to species composition, size, developmental stage and sex (Table 1).
Fig. 1. Thysanoessa inermis infected by Collinia beringensis. Photomicrograph shows the protargol-stained ciliate endoparasite (C. beringensis) from the haemocoel fluid of the krill. Note the irregular cell shapes caused by the extremely high ciliate densities found in some hosts

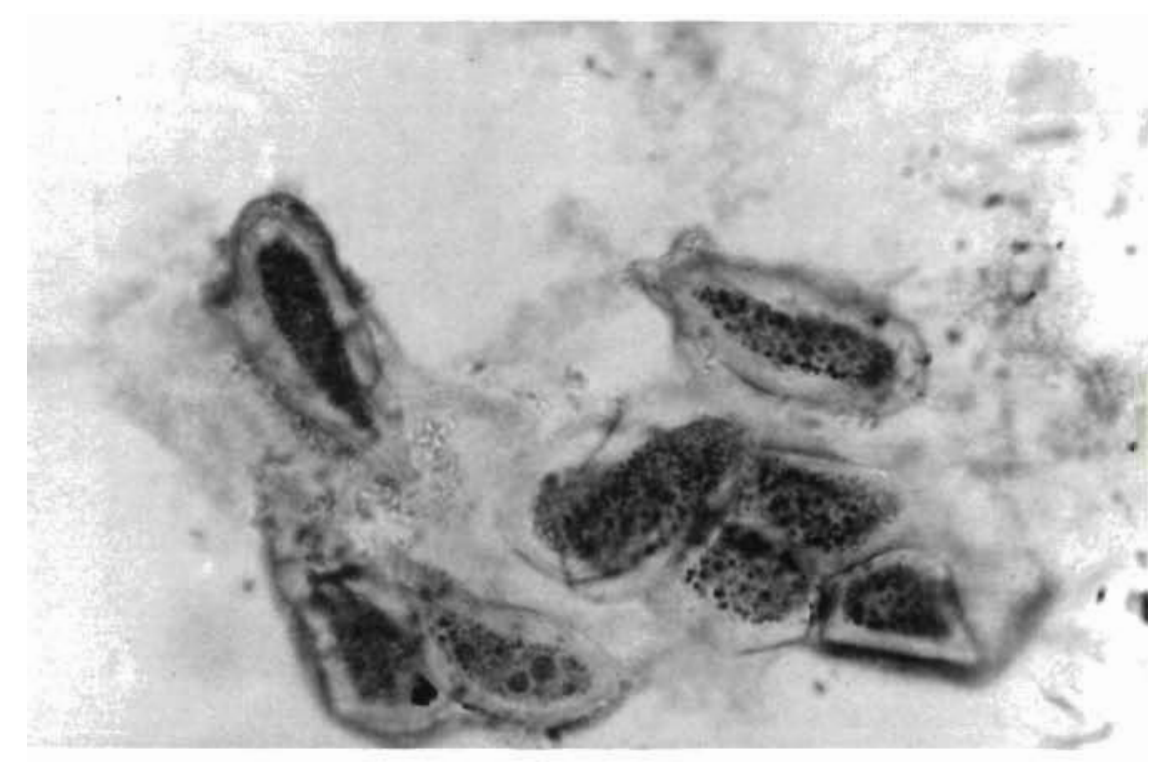


In order to determine the percentage of Thysanoessa inermis infected, 50 individuals were randomly taken (without regard to sex, developmental stage or size) from each sample. Each specimen was rinsed in water, placed under a dissecting microscope on a clean glass slide and cut open in the cephalothorax region. The krill was then removed, leaving the expelled body fluid, which was retrieved with the aid of a Pasteur pipette, on the slide. This fluid was treated with Lugol's solution (iodine-based fixative) to enhance cell contrast for microscope viewing. Slides were then examined under a compound microscope and apostome ciliate presence or absence was recorded. All dissecting instruments were rinsed off between surgical procedures to prevent contamination.

Results of this work indicate extreme infection rates in the 2 samples studied of 98 and $68 \%$ respectively (Table $2)$. The higher rate of $98 \%$ occurred in the sample containing the older and larger (mean carapace length $4.52 \mathrm{~mm}$ as compared to $3.98 \mathrm{~mm}$, Table 1) krill. Such rates are in marked contrast with those reported elsewhere in the literature for apostome ciliate krill ectoparasites (3 to $16 \%$; Lindley 1978). The physiological and ecological consequences for the krill harboring

Table 1. Thysanoessa inermis and Thysanoessa longipes. Krill population characteristics for nighttime horizontal plankton tow (1 mm mesh net) samples from Stns 2012 (2 May, surface water) and 2033 (8 May, $15 \mathrm{~m}$ depth) in 1981 in the Bering Sea. Measurements are based on examination of 102 and 105 randomly chosen individual krill from Stns 2012 and 2033, respectively. Mean carapace lengths $(C L)$ are presented \pm SD

\begin{tabular}{|c|c|c|c|}
\hline $\begin{array}{l}\text { Species } \\
\text { Sex (stage) }\end{array}$ & $\%$ Pop. & $n$ & Mean CL \\
\hline \multicolumn{4}{|l|}{ Stn 2012} \\
\hline \multicolumn{4}{|l|}{$T$ inermis } \\
\hline $\begin{array}{l}\text { Sub-adult } \\
\quad \text { (last furcilia stage) }\end{array}$ & 67.6 & 20 & $3.80 \pm 0.36$ \\
\hline Adult female (1st yr) & 19.6 & 15 & $4.38 \pm 0.33$ \\
\hline Adult male (1st yr) & 10.8 & 8 & $3.71 \pm 0.19$ \\
\hline \multicolumn{4}{|l|}{ T. longipes } \\
\hline Sub adult ${ }^{a}$ & 2.0 & - & - \\
\hline \multicolumn{3}{|c|}{ Grand mean ( $T$ inermis only, Stn 2012) } & $3.98 \pm 0.43$ \\
\hline \multicolumn{4}{|l|}{ Stn 2033} \\
\hline \multicolumn{4}{|l|}{$T$. inermis } \\
\hline $\begin{array}{l}\text { Sub-adult }{ }^{\mathrm{a}} \\
\quad \text { (last furcilia stage) }\end{array}$ & 11.4 & 7 & $4.31 \pm 0.38$ \\
\hline Adult female (1st yr) & 66.7 & 20 & $5.12 \pm 0.22$ \\
\hline Adult male (1st yr) & 21.9 & 20 & $3.99 \pm 0.30$ \\
\hline Grand mean (Stn 2033) & & & $4.52 \pm 0.60$ \\
\hline \multicolumn{4}{|c|}{$\begin{array}{l}\text { a Note that sex cannot be determined on sub-adult indi- } \\
\text { viduals due to the absence of secondary sexual charac- } \\
\text { teristics. However, the fact that the mean size of the sub- } \\
\text { adult population is greater than that of the adult males } \\
\text { indicates that a high percentage of sub-adults are females }\end{array}$} \\
\hline
\end{tabular}

Table 2. Thysanoessa inermis infected by Collinia beringensis. Percentage infection of Bering Sea euphausiids by apostome ciliate endoparasites

\begin{tabular}{|cc|}
\hline Stn 2012 & Stn 2033 \\
2 May 1981 & 8 May 1981 \\
\hline $68 \%(n=50)$ & $98 \%(n=50)$ \\
\hline
\end{tabular}

either ectoparasitic or endoparasitic (or both, as was observed in several of the Thysanoessa inermis we examined) apostome ciliates remain unknown. At this time, we can at best only speculate that some physiological impairment may be induced in the infected krill. No published works that we are aware of, but for that of Capriulo \& Small (1986) and the present contribution, report on endoparasitic ciliates in any species of euphausiid. While the high rates of infection reported here point towards a possible significant impact on krill population production/biomass, detailed studies on temporal and spatial occurrence of the parasite, on inter-specific euphausiid infections, and on growth and egg production rates for infected vs non-infected krill, as well as degree of infection in individual euphausiids, are needed before questions of trophodynamic significance can be quantitatively addressed.

Acknowledgements. We thank Dr Sharon Smith and Dominick Ninivaggi for providing us with the euphausiid samples, D. Ninivaggi for determining krill population characteristics and Jim Sneizik for SEM- and TEM-related assistance. This research was made possible in part by grants from the Hudson River Foundation for Science and Environmental Research and New York State Sea Grant (NOAA) (to G.M.C.) and NSF Grant DPP-76-23340 (to S.S.).

\section{LITERATURE CITED}

Capriulo, G. C., Small E. B. (1986). Discovery of an apostome ciliate (Collinia beringensis n. sp.) endoparasitic in the Bering Sea euphausiid Thysanoessa inermis. Dis. aquat. Org. 1: 141-146

Lindley, J. A (1978). Continuous plankton records: the occurrence of apostome ciliates (Protozoa) on Euphausiacea in the North Atlantic Ocean and North Sea. Mar. Biol. 46: $131-136$

Mauchline, J., Fisher, L. R. (1969). The biology of euphausiids. In: Russell, F. S., Yonge, M. (eds.) Advances in marine biology, Vol. 7 Academic Press, London, p. 1-454

Mauchline, J. (1980). The biology of mysids and euphausiids. In: Blaxter, J. H. S., Russell, F. S., Yonge, M. (eds.) Advances in marine biology, Vol. 18. Academic Press, London, p. $1-681$

This note was presented by Drs B. Sherr and E. Sherr, Corvallis, Oregon, USA

Manuscript first received: July 25, 1990

Revised version accepted: March 5, 1991 